\title{
ZAMIESZKANIE SŁOWA WCIELONEGO
}

Ewangelia według św. Jana różni się od Ewangelii synoptycznych nie tylko stylem języka i układem treści, ${ }^{1}$ ale również swoim „,duchem", którego istotą jest świadectwo - jak i reszty apostołów - naocznego świadka (J 1,14b). Świadectwo to przenika całe dzieło tego apostoła i ewangelisty, a wprost „wylewa się” w pierwszych słowach jego listu: „[To wam oznajmiamy], co było od początku, cośmy słyszeli o Słowie życia, co ujrzeliśmy własnymi oczami, na co patrzyliśmy i czego dotykały nasze ręce, bo życie objawiło się: myśmy je widzieli, o nim zaświadczamy i oznajmiamy wam życie wieczne, które było w Ojcu, a nam zostało objawione - cośmy widzieli i usłyszeli, oznajmiamy także wam, abyście i wy mieli współuczestnictwo z nami. A mieć z nami współuczestnictwo, znaczy: mieć je z Ojcem i Jego Synem Jezusem Chrystusem" (1J 1,1-3).

W tym wyznaniu w pismach Janowych po raz drugi i ostatni pojawia się rzeczownik własny „Słowo”, określający „Jezusa Chrystusa” - „Syna Ojca”, przedstawionego w Prologu czwartej Ewangelii i określonego kim jest i gdzie się umiejscowił: „A Słowo ciałem się stało i zamieszkało wśród nas. I oglądaliśmy Jego Chwałę, chwałę, jaką Jednorodzony otrzymuje od Ojca, pełen łaski i prawdy" (J 1,14). Te dwa miejsca pozwalają snuć domysły nie tylko co do etymologicznego i literackiego pochodzenia tego terminu w języku oryginalnym Nowego Testamentu, czyli greckim koine - Logos, ale również określić środowisko powstania głównego zrębu żydowsko-chrześcijańskiego hymnu, powstałego w diasporze w drugiej połowie I w. po Chr. M. Zerwick, po dokładnej analizie tekstu Prologu, stwierdza: „Z uprzednio istniejącego hymnu Jan uczynił swój Prolog,

1 Por. L. S t a c h ow i a k (oprac.), Ewangelia wedtug św. Jana. Wstęp-Przekład z oryginału-Komentarz, Poznań-Warszawa 1975, s. 37-43. 
modyfikując go, poszerzając i zważając, by jego zamierzony sens pozostał nietknięty". ${ }^{2}$ Opierając się na analizie R. Schnackenburga, ${ }^{3}$ biblista ten zrekonstruował pierwotną formę owego hymnu, za którego trafnością przemawia jego budowa oparta na układzie chiazmu. ${ }^{4}$

Układ ostateczny Prologu pozostał więc nietknięty, a „wstawki” tak zostały w niego włączone, by zapowiedzieć rolę Jana Chrzciciela nie jako światła, ale „świadka światłości” (ww. 6-8). To świadectwo zostało właśnie dodane do pierwotnego hymnu słowami: „Jan daje o Nim świadectwo i głośno woła w słowach: «Ten by, o którym powiedziałem: Ten, który po mnie idzie, przewyższył mnie godnością, gdyż był wcześniej ode mnie»” (w. 15). Owe Słowo istniało więc wcześniej, przed swoim poczęciem w łonie Maryi, podczas gdy w rzeczywistości doczesnej Jan, syn Zachariasza i Elżbiety, począł się wcześniej o sześć miesięcy, jak to uwydatnia ewangelista Łukasz (Łk 1,24-26). Przeświadczenie to znajduje odbicie w dalszej narracji ewangelicznej, rozpoczynającej się od nawiązania do chrztu Janowego. Wówczas Chrzciciel powtórzył to świadectwo, które zostało umieszczone na końcu Prologu: „Po mnie przyjdzie Mąż, który mnie przewyższył godnością, gdyż był wcześniej ode mnie" (J 1,30). W ten sposób „tradycyjny” początek Ewangelii, zachowany w Ewangeliach synoptycznych, ${ }^{5}$ rozpoczyna Jan - po Prologu - od opisu działalności

\footnotetext{
2 M. Z e rw i c k, Exegesis in Jo. 1,1-2,11, Romae 1962, s. 53.

3 R. S c h n a c k e n b u rg, Logos-Hymnus u. Johannes-Prolog, Biblische Zeitschrift Neue Folge 1/1956, s. 69-109.

4 Od gr. chiasmos - „skrzyżowanie”, na wzór litery chi (X) - symetryczny układ krzyżowy dwóch paralelnych zdań lub zwrotek literackich. Jego rekonstrukcja, wg M. Zerwicka, składa się z czterech strof, z których I i IV (ww. 1 i 3 - 14 i 16) krzyżują się z II i III (ww. 4 i 9 - 10 i 11); por. M. Z e r w i c k, Exegesis in Jo $1,1-2,11$, s. 51. Chiazm struktury wersetów potwierdza ich znaczenie. Układ wersetów I - bóstwo Logosu i jego uczestnictwo w stworzeniu łączy się z wersetami IV - wcielenie Słowa jako końcowy punkt szczytowy hymnu, podczas gdy układ II i III - krzyżujący się z pierwszym - mówi o życiu Słowa jako niepoznanego światła i przez ,swoich” odrzuconego.

5 Mateusz i Łukasz poprzedzają ten początek narracją o okresie dziecięctwa Jezusa: Mt 1-2; Łk 1-2; por. O. d a S p i n e toli, Introduzione ai Vangeli dell'Infanzia, Brescia 1967.
} 
Jana Chrzciciela i jego wzmiance o „Duchu Świętym, który zstępował jak gołębica i spoczął na Nim" po chrzcie (J 1,32).

Właśnie pierwsza w kreśleniu kreska litery greckiej X ( $\chi i ́$ „chi”) - łącząca pochodzenie i istotę „Słowa” z jego wcieleniem się, wskazuje na kulminacyjny werset Prologu: „A Słowo ciałem się stało i zamieszkało wśród nas" (w. 14). Całe znaczenie tego stwierdzenia tkwi w starotestamentowym objawieniu, co potwierdza pochodzenie głównej części Prologu od wczesnochrześcijańskiego hymnu o „Słowie". W rzeczywistości wyraża on prawdę o tajemnicy wcielenia, ale z jej egzystencjalnym i antropologicznym znaczeniem „zamieszkania wśród nas", ${ }^{6}$ tak dobitnie podkreślanego w Starym Testamencie, od pierwszych słów Jahwe: „I uczynią Mi święty przybytek, abym mógł zamieszkać pośród was” (Wj 25,8), do ostatniego: „Powrócę znowu na Syjon i zamieszkam znowu w Jeruzalem" (Za 8,3).

Nikt z uczonych i mędrców Izraela nie dopuszczał myśli, by ten „powrót” dokonał się „materialnie”, jak to ujął Jezus w wypowiedzi do Nikodema: „Tak bowiem Bóg umiłował świat, że Syna swego Jednorodzonego dał, aby każdy, kto w Niego wierzy, nie zginął, ale miał życie wieczne" (J 3,16).

\section{Istota i relacje Słowa}

Określenie istoty i relacji Słowa (Logos) w Prologu rozpoczyna się od pierwszego terminu pierwszej księgi Starego Testamentu berēszit - „na początku” (Rdz 1,la), oddane greckim zwrotem en $\operatorname{archè~(J~1,1a).~Poza~tymi~dwoma~tożsamymi~zwrotami~to,~co~na-~}$ stąpiło „na początku”, różni się diametralnie. W Prologu bowiem nie jest zapowiadany początek świata, lecz przekroczenie tego początku i sięgnięcie do Tego, który był już obecny „na początku”, czyli był „,przed początkiem”. Dlatego też już „na początku było Słowo...”.

6 Por. ks. M. C z aj k ow s k i, Egzystencjalna lektura Biblii, Lublin 1993, s. 7-10 (zamieszczenie tytułu „ks.” w tym przypadku jest spowodowane identycznym zwrotem „M. Czajkowski”, w którym „M” jest skrótem „Marian” - autor Biblia dziś odczytana - a nie ks. Michał Czajkowski). 


\section{Istota Słowa}

Gdy więc zaistniał ,początek” świata, Słowo już istniało. Istnienie było Jego istotą, wiecznym „Jest" z samego siebie, w sobie i przez siebie. Dlatego twórczy i poszukiwawczy umysł ludzki nie zadowala się powierzchownym znaczeniem początku, lecz szuka i powinien szukać, co było przed tym początkiem, i znaleźć Byt, który nie ma początku, co zdaje się oddawać trzykrotne powtórzenie „było” (ēn): "Na początku było Słowo, a Słowo było u Boga, i Bogiem było Słowo" (J 1,1).

Na początku tej pierwszej strofy Prologu - inicjującej wspomniany i przyjęty chiazm - nie ma mowy o stworzeniu, ale o Słowie samym w sobie, nie w znaczeniu sformułowanej myśli Boga czy Jego słowie-mowie, lecz o Słowie „u Boga” (pros ton Theon). Jest Ono ze swej istoty transcendentne, a ta Jego „transcendencja” jest jedyna w swoim rodzaju w odniesieniu do wielu przyczyn, ${ }^{9}$ jest ze swej istoty boska, ponieważ znajduje się w Bogu, ale nie tak jak starotestamentowa Mądrość, ponieważ „Bogiem było Słowo”. Jest On Jeden, ale ma w sobie „dwoistość”, która okaże się ,jednością troistą” po ujawnieniu się Ducha Świętego i Jego zesłaniu (Dz 2,1-21).

7 Hebrajskie formy czasownikowe nie wyrażają czasu, ale trwanie albo dokonanie działania; por. C.H. V o s e n, Kurze Einleitung zum Erlernen der hebräischen Sprache, Freiburg 1900, s. 19. Izrael więc pisał i mówił „był”, ale przeżywał je w swojej świadomości jako ,jest”, szczególnie w odniesieniu do Boga, który nazwał się „Jestem” (Wj 3,14). Dlatego R. B r a n d s t a e t t e r - jako Żyd doskonale wyczuwający „ducha” biblijnego języka hebrajskiego - w swoim tłumaczeniu Ewangelii według św. Jana przełożył pierwsze słowa Prologu: „Przed wszystkim Jest Słowo...”; t e n ż e, Pisma Świętego Jana Ewangelisty. Ewangelia - Listy Apokalipsa, Warszawa 1978, s. 11.13.

8 Por. R. Gut z w i 11 e r, Meditazioni su Giovanni, Milano 1961, s. 54.

$9 \quad$ Opierając się na Biblii, nie należałoby mówić o przyczynie pierwszej i przyczynach wtórnych, lecz - posługując się językiem naszych czasów - o przyczynie transcendentnej, którą jest Bóg, i przyczynach kategorialnych, którymi są człowiek i natura. Przyczyna transcendentalna nie jest przyczyną działającą „obok naszych” przyczyn, lecz działa we wszystkich, nie będąc nimi, tylko sprawiając, że one mogą być w ogóle przyczynami; por. M. Czajkowski, Biblia dziś odczytana, Warszawa 1988, s. 22. 
Tę osobową „troistość” A.L. Schökel tak stara się wyjaśnić. Tak jak każdy z nas ma na własność swą wiedzę o sobie i świadomość swojej osobowości, podobnie Bóg ma sam siebie, z tą jednak różnicą, że swoją pełnię może mieć tylko On i to niezależnie, czy jest ona własnością Ojca, Syna i Ducha. Ojciec, posiadając pełnię Bóstwa, nie zastrzega jej tylko dla siebie, lecz przekazuje ją wewnętrzną „wypowiedzią-słowem” swojemu Synowi. W ten sposób Syn ma tę samą pełnię bóstwa, co Ojciec. ${ }^{10}$ Gdyby się zdarzyło, że jakiś syn posiadałby wszystko to, co ma jego ojciec, wtedy moglibyśmy powiedzieć, że jest wiernym „odbiciem” ojca. W podobnym znaczeniu - ale wykraczającym poza owo podobieństwo w ludzkim znaczeniu - Syn Boży jest doskonałym „Obrazem” i „Wypowiedzią-Słowem” Ojca, tak że Jezus mógł powiedzieć do Filipa: „Kto Mnie widzi, widzi także i Ojca" (J 14,9). Tę pełnię bóstwa - jaką mają Ojciec i Syn przekazują oni Duchowi, jednak nie „słowem”, gdyż Ono już się odwiecznie ,wypowiada”, lecz przez miłość, tak więc trzecia osoba Trójcy Świętej ma tę samą pełnię bóstwa. Można więc powiedzieć, że życie Boże jest wzajemnym przejawianiem się wewnętrznym Trójjedynego Boga. ${ }^{11}$

\section{Relacja Słowa ze światem}

Podczas gdy w pierwszej części Prologu (J 1,1-2) pojawia się trzy razy czasownik „było” (ēn), w drugiej (w. 3) znajduje się trzykrotny termin ,stało się” (egeneto), ${ }^{12}$ odnoszący się do Słowa w Jego relacji do świata: „Wszystko przez Nie się stało, a bez Niego nic się nie stało, [z tego], co się stało" (w. 3). Czasownik ,stało się” zachodzi wówczas, gdy coś lub ktoś nie istniał, ale zaistniał, dzięki przyczynie transcen-

10 Por. słowa Credo - ,zrodzony, a nie stworzony, współistotny Ojcu”.

${ }^{11}$ Zbior., La parola ispirata. La Bibbia alla luce della scienza del linguaggio, Brescia, 1967, s. 18.

12 E-geneto-aor² od ginomai - „stawać się”, „rodzić się”, tu „o stawaniu się za czyjąś sprawą"; M. Z e r w i c k, Analisis philologica Novi Testamenti graeci, Romae 1966, s. 211; R. P o p o w s k i, Wielki stownik grecko-polski Nowego Testamentu, Warszawa 1997, s. 108-110. 
dentnej - którą jest Bóg - przyczynie dającej początek wszystkim przyczynom kategorialnym, występujących w stworzonym świecie. ${ }^{13}$ $\mathrm{W}$ ten sposób powstaje przeciwstawne zestawienie. $\mathrm{Z}$ jednej strony Bóg, który „Jest” od zawsze (Wj 3,14), z drugiej wszystko, co nie jest Bogiem, a zostało przez Niego powołane do bytu. Termin „wszystko” jest zawarty w Credo. Są to „rzeczy widzialne i niewidzialne”, czyli materialne i duchowe, tworzące wszechświat z ich istotami żywymi. To wszystko „przez Nie się stało”, to jest przez Słowo.

Prawdę tę wyrażają pierwsze słowa Listu do Hebrajczyków, dotyczące Syna Bożego, którego Bóg „ustanowił dziedzicem wszystkich rzeczy, przez Niego też stworzył świat” (Hbr 1,2). Przyimek ,„przez” rządzący biernikiem wskazuje na Słowo, które „ciałem się stało” (J 1,14), na Jego moc stwórczą, przejawiającą się w uzdrowieniach chorych, wskrzeszeniach zmarłych, panowaniu nad zjawiskami natury i demonami, a przede wszystkim w ,stwarzaniu nowego człowieka" przez odpuszczenie grzechów (Mk 2,1-12; Łk 7,35-50). Ta moc przeszła na Ciało mistyczne Słowa Wcielonego, którym jest Kościół, mający szczególnie nadludzką siłę słów konsekracji eucharystycznej czy sakramentalnego odpuszczania grzechów, jak również moc słów błogosławieństwa i obrzędów liturgicznych. ${ }^{14}$

To stworzenie ,przez” Słowo jest dopełnione zwrotem negatywnym: „a bez Niego nic się stało, [z tego], co się stało” (w. 3). W tym sformułowaniu tkwi optymistyczne pojęcie wszechświata, radosne poświadczenie całej rzeczywistości stworzonej, relacja z Bogiem wszystkiego, co zaistniało dzięki Niemu i Jego Słowu. Prawda ta daje człowiekowi możliwość poznania tej Bożej relacji przez poznawanie Jego dzieła stwórczego i dochodzenie do jego Stwórcy. Tę drogę wiodącą do Boga św. Jan Paweł II ujął pojęciem zdumienia: „Potok się nie zdumiewa, gdy spada w dół i lasy milcząco zstępują w rytmie potoku - lecz zdumiewa się człowiek! Próg, który świat w nim przekracza, jest progiem zdumienia. (Kiedyś temu właśnie

13 Por. M. C z a j k ow s k i, Biblia dziś odczytana, s. 22.

14 Por. R. Gut z w i 11 e r, Meditazioni su Giovanni, s. 59. 
zdumieniu nadano imię «Adam»)". ${ }^{15}$ Jest to zdumienie wyrażane przez jedyną istotę żywą, zdolną od skutków dochodzić do przyczyny, przez rzeczy stworzone do niestworzonego ich Sprawcy, czyli przez objawienie naturalne, zwane również kosmicznym. ${ }^{16}$

\section{Relacja Słowa z człowiekiem}

Na pierwsze miejsce tej relacji wysuwa się znaczenie ludzkiego słowa, które upodabnia się do słowa Bożego, tak jak słowo Boże do słowa człowieka, z uwzględnieniem jego odmienności, wyrażonej słowami, skierowanymi przez usta Izajasza do Izraela: „Bo myśli moje nie są myślami waszymi ani wasze drogi moimi drogami wyrocznia Pana" (Iz 54,8). Jednak jedno i drugie mówienie w swojej ekspresji jest uchwytne i odczytywalne, dzięki obecności w słowie Bożym i dziele stwórczym „Słowa”, które „było na początku” (J 1,1). Słowo ludzkie ma więc pewne podobieństwo do słowa Bożego, z racji podobieństwa słowa Bożego do ludzkiego i ,spotkania się” tychże słów już w zakresie i ciągu objawienia historycznego, ${ }^{17}$ dokonującego się w historii starotestamentowego Izraela. „Mówienie” Boga przeżywał on w swojej historii jako naród, który - jak wszystkie ludy semickie - głęboko interesował się swoimi początkami. I oto na początku procesu, rzucającego światło na jego historię, odkrył zasadę absolutną: słowo Jahwe, wzywające Abrama do opuszczenia swojej ziemi i domu rodzinnego (Rdz 12,1-3). Jego późniejsza historia jest nieustannym doświadczaniem tego słowa i mocy Jahwe, który wyprowadził go z Egiptu, wprowadził do Ziemi Obiecanej i wspomagał w każdym niebezpieczeństwie, radząc, co było dla Izraela dobre, ostrzegając przed złem i karcąc jego grzeszne postępowanie (Pwt 7,11-13). ${ }^{18}$ Tak rozumiane ,słowo” - w tekście hebrajskim Starego

\footnotetext{
15 J a n P a w eł II, Tryptyk rzymski, Kraków 2003, s. 10.

16 Por. R. L a t o u r e 11 e, Teologia della rivelazione, Assisi 1967, s. 27.

17 Tamże, s. 28.

18 Por. L.R. M or a n, Chrystus w historii zbawienia, Warszawa 1982, s. 31.
} 
Testamentu $d \bar{a} b \bar{a} r, \mathrm{w}$ aramejskich targumach $m \bar{e} m r \bar{a}^{19}$ - grecka Septuaginta przekłada przez rhemata lub logos (Pwt 5,5; 28,14). Ten drugi termin występuje właśnie w Prologu i określa „Słowo” (Logos), które „było Bogiem”, czyli Syna Bożego, istniejącego „u Boga” (J 1,1). Znaczenie „tego” Logosu odpowiadałoby aramejskiemu Mēmrā Adonaj„Słowo Pana"- określającego samego Boga, co może być brane za podstawę do Janowego Logosu, większość jednak biblistów dopatruje się zależności użycia tego terminu od biblijnego pojęcia „mądrości” (hebr. $h \bar{o} k m \bar{a}$ ), występującego głównie w księgach mądrościowych (sapiencjalnych) i dziełach późnego judaizmu. W tych źródłach mądrość jawi się jako przymiot Boży usamodzielniony, zbliżony do personifikacji cech abstrakcyjnych (hipostaza). Poprzedza ona czas (Prz 8,22-26; Syr 24,9), stoi przy tronie Bożym (Mdr 9,4.10), jest obecna przy stworzeniu i bierze w nim udział (Prz 8,27-30; Mdr 7,21; 8,6; 9,9), zstępuje na ziemię, szukając zamieszkania u ludzi, ale odrzucona wraz ze swoim orędziem, wraca do nieba i przebywa w nim (Syr 24,7; Prz 1,20-32). Znajduje jednak schronienie wśród ubogich duchem, czyniąc ich przyjaciółmi Boga i Jego prorokami (Mdr 7,27-28), a dopiero utożsamiona z Prawem, zamieszkuje w Izraelu (Syr 24,23-25).

Zdaniem A. Wikenhausera, Prolog Janowy zależy od owych stwierdzeń o Mądrości, z czego korzystał Paweł, pisząc o preegzystencji Chrystusa, szczególnie jako pośrednika w dziele stwórczym (Kol 1,16; por. Hbr 1,2). Jeśli w tym Prologu zamiast terminu „Mądrość" został użyty termin Logos, stało się tak, ponieważ wiąże się on z opisem stworzenia, w którym występuje w formie od „mówić”, „wypowiadać się” (gr. eipen; od lego) w pełnej liczbie, czyli dziesięć razy (Rdz 1,3.6.9.11.14.20.24.26.28.29; LXX) ${ }^{20}{ }^{20}$ Należy też wziąć pod uwagę fakt, że termin „mądrość” w językach semickich i greckim - a nawet współczesnych - występuje w rodzaju żeńskim, a więc trudno go było zastosować do Chrystusa.

19 F. Z o r e 1 1, Lexicon graecum Novi Testamenti, Parisis 1961, s. 779-780.

20 Por. D. F o r s t n e r, Świat symboliki chrześcijańskiej, Instytut Wydawniczy Pax, Warszawa 2001, s. 50-51. 
Rozważania te nie wyjaśniają jednak przekonująco genezy Janowego Logosu, tak że trzeba by szukać jej poza środowiskiem palestyńskim, czyli w hellenistycznym, jednak nie w kręgach stoików, uznających Logos za ,zasadę, sens, rację, prawo”. ${ }^{21}$ Nawet teoria Żyda w diasporze Filona z Aleksandrii (10 r. przed Chr. -40 r. po Chr.), ${ }^{22}$ który był twórcą gradualistycznej metafizyki aleksandryjskiej (Bóg Logos - świat materialny), nie wywarły wpływu na myśl żydowsko-chrześcijańską i spotkały się z dużym zainteresowaniem m.in. św. Ignacego, który w Liście do Magnezjan porównuje Chrystusa do Logosu. Pisze w nim, że prorocy byli prześladowani za to, ,że głosili Jezusa Chrystusa jako Boga, Słowo (Logos), które wyszło z Milczenia i dokonało wszystkiego na rzecz Tego, który Je posłał" (Magn. 8,2). W tej wypowiedzi „Milczenie” - podniesione do rangi hipostazy jest „Bogiem ukrytym”, podczas gdy „Słowo-Logos” jest w tejże hipostazie „Bogiem ujawniającym się”. ${ }^{23}$

Zdaniem większości egzegetów właśnie to środowisko żydowsko-chrześcijańskie i wczesnochrześcijańskie wpłynęło na twórcę hymnu, stanowiącego rdzeń Prologu, by na określenie Jezusa Chrystusa użyć terminu Logos. Należy jednak podkreślić, że racja tego wyboru nie dotyczy Prologu, tylko owego środowiska, choć znajduje swoje zastosowanie w pełnym jego tekście, którego „wstawki” czynią go utworem ewangelicznym, mimo że w Ewangelii według św. Jana tytuł „Słowo” nie występuje ani razu.

\section{Ujawnienie się Słowa}

Dokonywało się ono od chwili stworzenia świata, jako „,̇ycie i światłość ludzi”. Mimo że „na świecie było”, a świat stał się przez

21 Są to tylko cztery z kilkudziesięciu znaczeń terminu logos; Z. A b r a m o w i c z ó w n a, Słownik grecko-polski, Państwowe Wydawnictwo Naukowe, Warszawa 1962, t. III, s. 43-46.

22 Por. A. Św i d e r ków na (red.), Słownik pisarzy antycznych, Warszawa 1990, s. 359.

23 Por. A. W i k e n h a u s e r, Origine della nozione Logos in Giovanni, w: t e n ż e, L'Evangelo secondo Giovanni, Morcelliana, Brescia 1962, s. 78. 
Nie”, nie zostało poznane, nawet w „swojej własności”, czyli w Izraelu (J 1,4.5.9.11), z wyjątkiem tych, „którzy Je przyjęli” i wówczas „z Boga się narodzili” (ww. 12-13). Te dane występują w drugiej „kresce” chiasmu, podczas gdy pierwsza - w minuskuli zakrzywiona $(\chi)$ - tworzy główny wątek Prologu, jak to podaje skośny zapis owej „kreski”:
${ }_{11}^{1}$ Na początku było Słowo,
a Stowo było u Boga,
i Bogiem było Stowo.
${ }^{3}$ Wszystko przez Nie się stało,
a bez Niego nic się nie stało,
co się stało.
${ }^{14}$ A Słowo ciałem się stało
i zamieszkało wśród nas
pełne łaski i prawdy.
${ }^{16}$ Z Jego pełności
wszyscyśmy otrzymali
łaskę po łasce". ${ }^{24}$

To Słowo jest osobą duchową, boską, tworzącą jedno z Ojcem, które odwiecznie jest „u Boga” i ,jest Bogiem”. Właśnie „to” Słowo „ciałem się stało” (sarks egeneto).

\section{Tajemnica wcielenia}

W Biblii na pierwsze miejsce pojęcia „ciało” (hebr. $b \bar{a} \hat{s} \bar{a} r-$ „ciało zwierzęcia”, „mięso”; „ciało człowieka”; „,iało zmarłego”) ${ }^{25}$ wysuwa się jego przemijalność, słabość, miejsce chorób, czyli strona cielesna człowieka, wymieniona przykładowo w Księdze Joela: „I wyleję potem Ducha mego na wszelkie ciało...” (J1 3,1), czy w Księdze Rodzaju:

24 Por. M. Z e r w i c k, Exegesis in Jo. 1,1 - 2,11, s. 53. Kursywa zastosowana do Słowa uwydatnia Jego boskość (ww. 1.3) i wcielenie (w. 14).

25 F. Z o r e 11, Lexicon graecum Novi Testamenti, s. 133. 
„Postanowiłem położyć kres istnienia wszystkich ludzi...” (Rdz 6,13; BT), dosłownie: „Koniec wszelkiego ciała [kōl-bāŝār] przyszedł przed oblicze moje". ${ }^{26}$ To samo znaczenie ma grecki odpowiednik sarks, „delikatniej” i bardziej filozoficznie oddający to pojęcie: „To, co pokrywa kości ludzi i zwierząt, substancja materialna w przeciwieństwie do niematerialnego ducha, ludzka natura". ${ }^{27}$ Tenże język - będący językiem oryginalnego tekstu Nowego Testamentu - ma jeszcze drugi termin na określenie „ciała” - sōma. Oddaje ono godność ciała ludzkiego, „coś” więcej od jego mięsności, co wykorzystuje św. Paweł (Rz 1,24; 4,19; 1Kor 7,4; 6,13-20) ${ }^{28}$ i synoptycy w formule konsekracji, wypowiadanej przez Jezusa: Touto estin to sōma mou - „To jest Ciało moje" (Łk 22,19). ${ }^{29}$ Ciało więc oglądane od strony zniszczalności i słabości człowieka oddają terminy: greckie sarks i łacińskie caro, natomiast od strony godności i możliwości stania się nawet ,świątynią Ducha Świętego" (1Kor 6,19) - gdyż zostanie przemienione w ,ciało chwalebne” (Flp 3,21) - zawierają terminy sōma i corpus. ${ }^{30}$ „Słowo ciałem stało się" (Logos sarks egeneto), a więc stało się człowiekiem prawdziwym z tego świata, ${ }^{31} \mathrm{z}$ wszystkimi jego ograniczeniami, lecz jednocześnie człowiekiem, w którym wierzący widzą i uznają Syna Bożego i Odkupiciela, wydającego swoje ciało pełne godności i niepokalane ${ }^{32}$ na cierpienia i godzącego się na śmierć

26 A. K u śm i r e k (oprac.), Hebrajsko-polski Stary Testament. Pięcioksią, Warszawa 2003, s. 20.

27 R. P o p ow s k i, Wielki słownik grecko-polski Nowego Testamentu, s. 550-551.

28 Paweł chronologicznie pierwszy utrwalił na piśmie formułę konsekracji (1Kor 11,23-27).

29 Łacina, podobnie jak język grecki, ma te same odpowiedniki podwójnego nazewnictwa terminu ,ciało”; sarks - caro, oraz sōma-corpus.

30 X. L é o n - D u fou r (red.), Słownik teologii biblijnej, Poznań-Warszawa 1973, s. 140-147.

31 Tamże, s. 142.

32 Oto wymowna wypowiedź z listu o. Augustyna do o. Pio z Pietrelciny z 22 II 1913 r., udowadniająca niepokalane poczęcie Maryi i niepokalaność Jezusa: „Ponieważ Syn dał istnienie swojej Matce, a Matka dała istnienie swojemu Synowi, musimy albo mówić, że został splamiony Syn, albo inaczej, że była bez zmazy 
krzyżową ${ }^{33}$ Stało się wówczas to, co tak ujmuje św. Jan Paweł II: „W tym zbawczym wydarzeniu dzieje człowieka w Bożym planie miłości osiągnęły swój zenit. Bóg wszedł w te dzieje, stał się - jako człowiek - ich podmiotem, jednym z miliardów i równocześnie Jedynym! Ukształtował przez swe Wcielenie ten wymiar ludzkiego bytowania, jaki zamierzył nadać człowiekowi od początku". ${ }^{34}$

Wcielenie Słowa można porównać do najbardziej śmiałego i nieprzewidywalnego przerzucenia mostu, łączącego niebo z ziemią, wieczność z czasem, Nieskończonego ze skończonym, Stworzyciela ze stworzeniem, Byt w sobie sam istniejący z bytem otrzymującym istnienie i uczestniczącym w tymże Bytem przez ,adopcję”, zaistniałą dzięki dziełu odkupienia (Rz 8,14-17). ${ }^{35}$ To uczestniczenie zaistniało z chwilą wcielenia, kiedy „Słowo ciałem się stało” w momencie zgody Maryi: „Oto ja służebnica Pańska, niech mi się stanie według słowa [gr. rhema] twego" Łk 1,38). W omawianym tekście jego tok myśli łączy nie tylko trzynaście razy występujący spójnik ,i” (gr. kai), ale kilkakrotny czasownik egeneto - „stało się” z odwieczne postanowionym przeznaczeniem: ,zamieszkania wśród nas”.

\section{Rozbicie namiotu przez Słowo}

Tekst grecki Prologu „zamieszkanie Słowa” oddaje hebraizmem: „, rozbił namiot wśród nas” (kai eskēnōsen en hēmin). Czasownik

Matka"; Padre Pio da Pietrelcina, Epistolario I. Corrispondenza con i direttori spirituali (1910-1922), San Giovanni Rotondo 2000, s. 333.

33 Można przypuszczać, że formę chiazmu wczesnochrześcijańskiego hymnu O Logosie mógł inspirować znak krzyża zwany crux decussata (od decusso - „podzielić na krzyż ukośny”), czyli krzyż w kształcie litery X; A. J o u g a n, Słownik kościelny łacińsko-polski, Warszawa-Lublin 1958, s. 177. Nawet gdyby inspiracja ta nie miała miejsca, tego kształtu krzyż - zwany krzyżem św. Andrzeja - przypominał tytuł mesjański Chrystusa (XPICTOC), utrwalany na najwcześniejszych ikonach, np. IC - XC; Jesous Christos; por. Ilustracja 24, w: D. F o r s t n e r, Świat symboliki chrześcijańskiej, s. 31.

34 J a n Paw eł II, Encyklika Redemptor hominis, Watykan 1979, nr 1.

35 Por. R. Gut z wi 11 e r, Meditazioni su Giovanni, s. 70. 
grecki eskēnōsen (skēnoō- „rozbijam namiot”, od skēnē- „namiot”, „mieszkanie") ${ }^{36}$ jest wiernym odpowiednikiem hebrajskiego szākan („,zamieszkać”, „mieć siedzibę”). ${ }^{37}$ Termin ten posłużył za podstawę sformułowania przez rabinów bardzo ważnego określenia: Szekina, ${ }^{38}$ oznaczającego właśnie „Zamieszkanie” Jahwe w Namiocie Spotkania, w którym spoczywała Arka Przymierza, jak to On sam zapowiedział w czasie zbierania materiałów na tenże namiot: „I uczynią Mi święty przybytek, abym mógł zamieszkać [weszākanti betokām] wśród was” (Wj 25,8). ${ }^{39}$ To ,zamieszkanie” się spełniło na pustyni i utrwaliło w świątyni wzniesionej przez króla Salomona - zastępującej Namiot Spotkania - który powtórzył słowa Jahwe: „«Pan powiedział, że będzie mieszkać [liszkon] w czarnej chmurze. ${ }^{40} \mathrm{Już}$ zbudowałem Ci dom na mieszkanie, miejsce przebywania Twego na wieki»" (1Krl 8,12-13). ${ }^{41}$

To „przebywanie na wieki” transcendentnego Boga we wspólnocie starotestamentalnego Izraela - a więc w rzeczywistości etnicznej i historycznej - weszło w fazę ,pełni”, gdy „Bóg zesłał swojego Syna, zrodzonego z niewiasty, zrodzonego pod Prawem" (Ga 4,4). Właśnie Jego poczęcie oddaje rozpatrywany werset Janowego Prologu:

36 Por. R. P o p ow s k i, Wielki słownik grecko-polski Nowego Testamentu, s. 557.

37 F. Z o r e 11, Lexicon hebraicum et aramaicum Veteris Testamenti, Rome 1940, s. 481-482.

38 Termin ten zastępował imię Jahwe; por. R.E. B r ow n, J.A. F i t z m y e r, R.E. M u r p hy (red.), Grande commentario biblico, Brescia 1973, s. 1378. Polskie tłumaczenie tego obszernego dzieła: Katolicki komentarz biblijny, Warszawa 2001, s. 1122, nie zamieszcza tego szczegółu.

39 A. K u ś m i r e k (oprac.), Hebrajsko-polski Stary Testament. Pięcioksiag, s. 305. Tłumaczenie na język hebrajski zwrotu ,,i zamieszkało wśród was” (J 1,14a) brzmi podobnie: wajjiszkon betōkēnu (Księga Przymierza Nowego. Przekład z greckiego na język hebrajski, London, brak roku wydania i tłumacza. Druk: Szemuel Begester i Synowie jego).

40 „Chmura” - inaczej „obłok” - symbolizowała „Chwałę” (Kābōd) Jahwe; por. P.J. A c h t e m e i e r (red.), Encyklopedia biblijna, Warszawa 1999, s. 161-162.

${ }^{41} \mathrm{~W}$ przytoczonych w nawiasie terminach hebrajskich znajdują się zawsze trzy litery pojęciowego rdzenia „zamieszkać” $-s z-k-n$. 
„A Słowo ciałem się stało i zamieszkało wśród nas” (J 1,14). Jest to kontynuacja starotestamentowego „zamieszkania” Jahwe w Izraelu ostatecznie dopełnionego „osobiście” przez osobę Syna Bożego, który „rozbił namiot wśród nas”. Czasownik eskēnōsen jest powszechnie tłumaczony - począwszy od łacińskiej Wulgaty z IV-V w., dzieła św. Hieronima (ok. 340-420) ${ }^{42}$ - przez „zamieszkać”, na co pozwala zakres tego terminu, tożsamy w swoim znaczeniu z katoikeō „mieszkać”, „przebywać” (od kata i oĩkos - „dom”), ${ }^{43}$ sugerujący stałe miejsce pobytu. Tymczasem w starotestamentalnych Księgach Świętych położony jest nacisk na pojęcie i termin zamieszkania jako „rozbicia namiotu”, czyli ruchome i przenośne miejsce zamieszkania razem z Namiotem Spotkania. Jeszcze prorok Ozeasz (VIII w. przed Chr.) powtarzał słowa Jahwe, skierowane do Izraela: ,Jam jest Pan Bóg twój, od ziemi egipskiej, sprawię, że jeszcze zamieszkasz w namiotach, jak było za dni spotkania" (Oz 12,10).

Owo „zamieszkiwanie” w okresie wędrówki przez pustynię do Ziemi Obiecanej stało się więc wiecznie istniejącym wzorcem życia, będącego bezustanną wędrówką z przenośnym „domem” - namiotem, razem z przenośną pierwszą świątynią - Namiotem Spotkania, miejscem uobecnienia się Boga i „spotkania się" z Nim, podobnie jak spotykają się mieszkańcy tego samego obozu, który widział Balaam, patrząc na namioty Izraela w Moabie: „Jakubie, jakże piękne są twoje namioty, mieszkania twoje, Izraelu" (Lb 24,5). Widział czarne tkaniny - utkane z sierści kóz czy wielbłądów ${ }^{44}$ - rozpięte na drążkach, jak i biegnące od nich sznury, przymocowane do kołków, wbitych w ziemię, a w miejscach, gdzie była lita skała, przyciśnięte do niej ciężkimi kamieniami. ${ }^{45}$ Ich jednak materialne części, rozkładane i przenoszone na inne miejsce pobytu, były „obrazem” niewidzialnego spotkania i „przebywania” ludu ze swoim Bogiem,

42 Por. A. Ś w i d e r k ó w n a (red.), Stownik pisarzy antycznych, s. 236-237.

43 Por. R. P o p ow s k i, Wielki słownik grecko-polski Nowego Testamentu, s. $332,423$.

${ }^{44}$ A. Van D e u r s e n, Dizionario biblico illustato, Casale 1957, s. 18, 90, 92.

45 Por. D. F o r s t n e r, Świat symboliki chrześcijańskiej, s. 365-367. 
uobecniającym się w Namiocie Spotkania, a następnie w świątyni jerozolimskiej z kamienia. Nawet wówczas, gdy ona stała na górze Moria (Rdz 22,2), oznaczała to, co „widział” prorok Izajasz, wołając do Izraela: „Patrz na Syjon, miasto naszych świąt! Twe oczy oglądać będą Jeruzalem, siedzibę bezpieczną, namiot nieprzenośny, którego kołków nie wyrwą nigdy ani się żaden jego powróz nie urwie" (Iz 33,30).

W tej wizji nie tylko świątynia, ale całe miasto - symbolizujące Ziemię Świętą z jej mieszkańcami - zawierało się w obrazie „namiotu” ze sznurami i kołkami, symbolizując rzeczywistość, którą dopełnił Prolog, wskazując na Jezusa Chrystusa jako „Słowo zamieszkujące” w nowotestamentowym Namiocie „wśród” naszych namiotów. Tworzą one rzeczywistość duchową, która razem z nami przeniesie się do nieba, jak to zapowiedział Chrystus: „Pozyskujcie sobie przyjaciół niegodziwą mamoną, aby gdy [wszystko] się skończy, przyjęto was do wiecznych przybytków [aiōvous skēnas], dosłownie „namiotów”. Rzeczywistość tę tak ujmuje nowotestamentowy pisarz natchniony: „Takiego mamy arcykapłana, który zasiadł po prawicy tronu Majestatu w niebiosach, jako sługa świątyni i prawdziwego przybytku [tēs skēnēs] zbudowanego przez Pana, a nie przez człowieka" (Hbr 8,1-2). W następnym rozdziale pisarz ten pogłębia tę prawdę: „Chrystus zjawiwszy się jako arcykapłan dóbr przyszłych, przez wyższy i doskonalszy, i nie ręką - to jest nie na tym świecie uczyniony przybytek [skēnēs] - ani nie przez krew kozłów i cielców, lecz przez własną krew wszedł raz na zawsze do Majestatu Świętego i osiągnął wieczne odkupienie" (Hbr 9,11-12).

List do Hebrajczyków, z wnikliwą treścią ewangeliczną ujętą pojęciami i słowami tkwiącymi w Starym Testamencie, naśladuje Jana w jego ujęciu wydarzeń w takim środowisku geograficznym i historycznym, w jakim nauczał Jezus, umarł na krzyżu i zmartwychwstał. Środowisko to było „starotestamentalne”. Czwarta Ewangelia zdradza wyjątkowe zainteresowanie Jerozolimą i świątynią, żydowskimi świętami i ich liturgią, które są głównymi ramami działalności Jezusa i miejscami objawienia. Jezus jest przedstawiony jako doskonały i właściwy uczestnik we wszystkich przejawach kultu Izraela i nic 
nie można byłoby zrozumieć z Jego gestów i słów bez odniesienia się do tego faktu. Dlatego paralelizm ze świątynią zajmuje dużo miejsca i tworzy doskonały „komentarz” do „Słowa”, które „stało się ciałem i zamieszkało wśród nas" (J 1,14), skoro zaraz na początku Ewangelii jawi się scena wypędzenia przekupniów z jej terenu, wytłumaczona przez Jezusa oświadczeniem, które stało się zarzutem podczas procesu, zakończonego śmiercią na krzyżu: „Zburzcie tę świątynię, a Ja w trzy dni wzniosę ja na nowo". Jan-pisarz tak wytłumaczył to bulwersujące stwierdzenie: „On zaś mówił o świątyni swego ciała” (J 2,19.21). Wkrótce Jan powrócił do tej prawdy, przytaczając rozmowę z Samarytanką i Jego stwierdzenie: „Wierz Mi, kobieto, że nadchodzi godzina, kiedy ani na tej górze, ani w Jerozolimie, nie będziecie czcili Ojca" (J 2,21).

Odpowiedź na pytanie ,gdzie?”, daje św. Paweł w wyznaniu, skierowanym do Kolosan: „Teraz raduję się cierpieniach dla was i ze swej strony dopełniam niedostatki udręk Chrystusa w moim ciele dla dobra Jego Ciała, którym jest Kościół” (Kol 1,24). To właśnie jemu została objawiona ta „odpowiedź” w drodze do Damaszku, Jezus mu powiedział, że prześladując chrześcijan, Jego prześladuje (Dz 9,4-5). Zamieszkał bowiem „wśród nich” i dzięki swojemu eucharystycznemu Ciału, zamieszkuje nie tylko „wśród nas”, ale „w nas”. To „zamieszkanie” - zapowiedziane w Prologu - tenże apostoł tłumaczy: „Kielich błogosławieństwa, który błogosławimy, czyż nie jest udziałem we Krwi Chrystusa? Chleb, który łamiemy, czyż nie jest udziałem w Ciele Chrystusa? Ponieważ jeden jest chleb, przeto my, liczni, tworzymy jedno ciało. Wszyscy bowiem bierzemy z tego samego chleba" (1Kor 10,16-17).

Przez „stanie się Słowem” Syn Boży i Syn Człowieczy nie tylko objawił ludziom sobą Ojca i Ducha, ale sprawił, że w Eucharystii daje siebie i Ich tym, którzy ją przyjmują.

$$
* * *
$$

Pośród bardzo licznych opracowań Prologu czwartej Ewangelii (J 1,1-18) wyróżnia się ten artykuł nowatorskim podejściem do tematu 
zamieszkania Słowa Wcielonego. Autor opiera swoje przemyślenia na przyjętej powszechnie tezie, że istotną treść tego Prologu stanowi wczesnochrześcijański hymn, powstały w drugiej połowie I w. w diasporze, odpowiednio dopracowany wstawkami, łączącymi go z Ewangelią według św. Jana. Całość tej jednostki literackiej hymnu tworzy tzw. chiazm, czyli krzyżowy układ wersetów, nazwany tak od litery greckiej X $(c h i-\chi)$. Autor wykorzystuje pierwszą „kreskę” takiego układu - tworzącego całość tematyczną istoty „Słowa”, przedstawianego w ww. 1.3 i wcielającego się ,w ciało” w ww. 14.16 - rozpracowując tematyczne wnioski, obejmujące ukazanie istoty Słowa z Jego relacjami ze światem i człowiekiem, a następnie Jego ujawnienie się w tajemnicy wcielenia i przez „rozbicie namiotu”, zgodnie ze znaczeniem greckiego terminu, tłumaczonego powszechnie przez „zamieszkanie”. Autor wykorzystuje ten hebraizm - oddany wiernie w greckim oryginale - i wiąże „mówiącego” Jahwe w starotestamentowym objawieniu i uobecniającego się w Namiocie Spotkania z nowotestamentowym pojęciem ,świątyni”, z którą utożsamił się Jezus (J 2,19), pozwalając w końcu na nawiązanie do Eucharystii.

\section{ks. Kazimierz PIERZCHAŁA}

Słowa kluczowe: Prolog czwartej Ewangelii, Słowo, świadectwo, Jezus

Keywords: The Prologue to the Fourth Gospel, the Word, Testimony, Jesus

\section{Inhabitation of the Incarnate Word} Summary

The author's views are founded on the thesis that the Prologue to the Fourth Gospel is based on an early Christian hymn from the second part of the $1^{\text {st }}$ century, originating in the diaspora, interwoven with additions that connect it with the whole Gospel. 